Jurnal Kesehatan

Volume 12, Nomor 2, Tahun 2021

ISSN 2086-7751 (Print), ISSN 2548-5695 (Online)

http://ejurnal.poltekkes-tjk.ac.id/index.php/JK

\title{
Pengaruh Suplementasi Fe dan Vitamin C terhadap Hemoglobin dan Indeks Eritrosit Remaja Putri
}

\section{The Effect of Iron and Vitamin C Supplementation on Hemoglobin and Erythrocyte Index in Teenager}

\author{
Endang Sri Wahyuni \\ Jurusan Gizi, Politeknik Kesehatan Tanjung Karang, Indonesia
}

\section{ARTICLE INFO}

\section{Article history}

Received date

16 Feb 2021

Revised date

08 Jun 2021

Accepted date

19 Jul 2021

Keywords:

Erythrocyte index;

Haemoglobin;

Supplementation iron;

Vitamin C,

Kata kunci:

Indeks eritrosit;

Hemoglobin;

Suplemen besi;

Vitamin C.

\begin{abstract}
ABSTRAK
Teenager girls are at risk of suffering from iron nutritional anemia. Anemic teenage girls also have less vitamin $\mathrm{C}$ intake. Anemia has an impact on learning achievement, ease of infection and impact when pregnant in the future. The study aimed to find out the effect of giving $\mathrm{Fe}$ and vitamin $\mathrm{C}$ tablets. The research design was a one-group pre-post test, using 41 Health Analyst female students from Tanjungkarang Health Polytechnic, which were determined by random sampling. Blood added tablets containing $60 \mathrm{mg} \mathrm{Fe}, 400 \mathrm{mcg}$ folate, and 500mg vitamin $\mathrm{C}$ tablets were given once/week for 17 days ( 3 tablets). $\mathrm{Hb}$ levels were measured before and after supplementation using a digital analyzer MINDRAY BC-3600. Data collection was conducted from August-September 2020. The proportion of $\mathrm{Hb}<12 \mathrm{mg} / \mathrm{dl}$ decreased from $20(48,78 \%)$ at before to $16(39,02 \%)$ subject after supplementation. The mean $\mathrm{Hb}$ level before supplementation was $12,15 \mathrm{mg} / \mathrm{dl}, \mathrm{MCV}$ $80,11 \mathrm{fL}, \mathrm{MCH} 25,85 \mathrm{lpg}$ and MCHC 32,22\% and after supplementation, the mean of $\mathrm{Hb}$ was $12,05 \mathrm{mg} / \mathrm{dl}$, MCV 79,83 MCH 26,45, and MCHC 33,07. The results of statistic test showed that supplementation had a significant effect on Hb levels ( $p$-value $=0,000)$ MCV (p-value $=0,000), \mathrm{MCH}(\mathrm{p}$-value $=0,000)$, and MCHC (p-value $=0,000)$. Supplementation can reduce the proportion of anemia and improve the erythrocyte index. Another research with longer duration time and nutritional education combination is needed to confirm the increasing of nutrient intake ( $\mathrm{Fe}$, vitamin $\mathrm{C}$ ) and $\mathrm{Hb}$ level.
\end{abstract}

\begin{abstract}
Remaja putri rentan terhadap anemia gizi besi. Sebesar $64,5 \%$ remaja putri mempunyai asupan vitamin $\mathrm{C}$ dalam kategori kurang. Anemia berdampak pada prestasi belajar, kemudahan terkena infeksi maupun dampak ketika hamil di masa yang akan datang. Penelitian bertujuan untuk mengetahui pengaruh pemberian tablet $\mathrm{Fe}$ dan vitamin $\mathrm{C}$. Rancangan penelitian adalah one group pre-post test, dengan 41 sampel mahasiswi Analis Kesehatan Poltekkes Tanjungkarang.yang ditentukan secara acak sampling. Tablet tambah darah mengandung Fe $60 \mathrm{mg}, 400 \mathrm{mcg}$ folat dan tablet vitamin C 500mg diberikan satu kali/minggu selama 17 hari (3 tablet) Kadar Hb diukur pada awal dan akhir penelitian menggunakan digital analizer merk MINDRAY BC-3600. Pengumpulan data dilakukan pada bulan Agustus-September 2020. Proporsi $\mathrm{Hb}<12 \mathrm{mg} / \mathrm{dl}$ menurun dari $20(48,78 \%)$ pada pre suplementasi menjadi $16(39,02 \%)$ subjek pada post suplementasi. Pada pre suplementasi rata-rata $\mathrm{Hb} 12,15 \mathrm{mg} / \mathrm{dl}$, MCV 80,11fL, MCH 25,85 lpg, dan MCHC $32,22 \%$. Pada post suplementasi rata-rata $\mathrm{Hb} 12,05 \mathrm{mg} / \mathrm{dl}$, MCV 79,83 MCH 26,45, dan MCHC 33,07. Hasil uji statistik menunjukkan ada pengaruh suplementasi terhadap kadar Hb ( $p$-value $=0,000), \operatorname{MCV}(p$-value $=0,000), \mathrm{MCH}(p$-value $=0,000)$, dan MCHC (p-value $=0,000)$. Suplementasi dapat menurunkan proporsi anemia dan memperbaiki indeks eritrosit. Diperlukan penelitian lanjutan dengan durasi yang lebih lama dikombinasi dengan edukasi gizi untuk memastikan adanya kenaikan asupan zat gizi (Fe dan vitamin C) serta kadar Hb.
\end{abstract}

Corresponding Author:

Endang Sri Wahyuni

Jurusan Gizi, Politeknik Kesehatan Tanjung Karang, Indonesia

Email: end_wahyuni71@poltekkes-tjk.ac.id 


\section{PENDAHULUAN}

Masa remaja merupakan masa pertumbuhan dan perkembangan yang ditandai adanya perubahan fisik, psikis dan kognitif yang sangat cepat (Fikawati, 2017). Usia remaja merupakan usia yang rentan untuk terjadi anemia, terlebih remaja putri (Fitriany \& Saputri, 2018). Anemia merupakan kondisi kadar hemoglobin yang rendah dalam darah. Remaja putri dikategorikan anemia ketika kadar hemoglobin darah $<12 \mathrm{mg} / \mathrm{dl}$. Sel darah merah mengandung hemoglobin yang membawa oksigen ke seluruh jaringan tubuh. Pada kondisi anemia, tubuh tidak mendapatkan oksigen sesuai kebutuhannya sehingga akan menimbulkan berbagai keluhan seperti mudah lelah (Fikawati, 2017).

Prevalensi anemia di negara sedang berkembang berkisar 25-50\% (Kumar, 2015). WHO memperkirakan sepertiga dari seluruh wanita usia subur mengalami anemia (WHO, 2016). Prevalensi anemia pada tahun 2013 sebesar $21,7 \%$ dan prevalensi anemia pada wanita usia subur sebesar 23,9\% (Kemenkes, 2015). Data anemia ibu hamil pada tahun 2013 sebesar $37,1 \%$ meningkat menjadi $48,9 \%$ pada tahun 2018 dengan distribusi terbesar pada rentang umur 15-24 tahun yaitu sebesar 84,6\% (Kemenkes RI, 2019). Anemia yang paling banyak terjadi di negara berkembang adalah anemia defisiensi besi (Kumar, 2015).

Remaja dan wanita usia subur merupakan golongan umur dengan prevalensi anemia yang tinggi (Fikawati, 2017). Pada masa remaja kebutuhan zat besi meningkat karena periode pacu tumbuh, dimana terjadi peningkatan masa otot, volume darah yang berdampak pada meningkatnya kebutuhan mioglobin di otot dan hemoglobin dalam darah. Peningkatan kebutuhan zat besi pada remaja putri memuncak pada usia 14-15 tahun. Pada masa ini remaja putri, mulai mengalami menstruasi setelah 1 tahun puncak pertumbuhan. Hal ini menyebabkan kebutuhan zat besi meningkati karena hilangnya zat besi pada saat menstruasi. Kehilangan zat besi karena menstruasi sebesar 12,5-15mg/bulan (Fikawati, 2017) atau $0,5 \mathrm{mg} \mathrm{Fe} / \mathrm{ml}$ (Fitriany \& Saputri, 2018).

Defisiensi zat besi (Fe) dapat menurunkan daya tahan tubuh (Kemenkes RI, 2019). Anemia dikaitkan dengan peningkatan morbiditas dan mortalitas, gangguan perkembangan kognitif dan perilaku. Penurunan ketersediaan zat besi memiliki efek negatif yang kuat pada perkembangan dan fungsi otak bahkan sebelum anemia berkembang (Chaparro \& Suchdev, 2019)

Konsumsi Fe dengan bioavailability yang rendah merupakan penyebab utama kekurangan Fe di negara berkembang (Kumar, 2015). Sumber makanan hewani (hati, daging, ikan ayam) mengandung $\mathrm{Fe}$ heme yang lebih mudah diabsorbsi dibandingkan $\mathrm{Fe}$ non heme yang terdapat pada kacang-kacangan maupun sayuran hijau (Hardinsyah, 2016). Vitamin C dapat membantu absorbsi besi non heme dengan mengubah feri menjadi fero yang lebih mudah diabsorbsi (Almatsier, 2012). Sebanyak 66,1\% remaja putri lebih sering mengkonsumsi makanan sumber zat besi non heme seperti kacangkacangan, sayuran hijau serta sering mengkonsumsi zat penghambat absorbsi zat besi seperti teh dan kopi. Adapun sebesar 64,5\% mempunyai asupan vitamin $\mathrm{C}$ dalam kategori kurang. Asupan vitamin $\mathrm{C}$ berhubungan positif dengan kadar hemoglobin pada remaja putri (Sholicha \& Muniroh, 2019). Penelitian lain menyatakan konsumsi enhancer zat besi tidak berhubungan dengan kejadian anemia (Masthalina, 2015)

Pemberian tablet $\mathrm{Fe}$ pada remaja putri diharapkan dapat memenuhi kebutuhan zat besi. Dengan demikian kejadian anemia ibu hamil, perdarahan saat persalinan, berat bayi lahir rendah dan balita pendek dapat diturunkan. Program pemberian tablet zat besi berupa tablet tambah darah (TTD) dosis 1 tablet/minggu, namun cakupan pemberiannya pada remaja putri di Indonesia tahun 2018 masih 48,52\%, dengan besaran cakupan di Provinsi Lampung sebesar 67,53\% (Kemenkes RI, 2019).

Penelitian pada 56 siswi SMP di Surabaya menunjukkan adanya hubungan antara anemia dan prestasi belajar pada siswi SMP ( $p$ value $=0,026$ ) (Dumilah \& Sumarmi, 2017). Suplementasi $\mathrm{Fe}$ dengan pemberian 1 tablet setiap minggu pada siswi selama 16 minggu di Tabriz menunjukkan adanya kenaikan $\mathrm{Hb}$ yang bermakna yaitu sebanyak $0,7 \pm 1,1 \mathrm{~g} / \mathrm{dl} \quad(p-$ value $=0,001$ ) (Bani, et al., 2014)

Penelitian eksperimental Randomize Control Trial (RCT) dengan subjek penelitian sebanyak 22 orang menunjukkan bahwa suplementasi Fe $200 \mathrm{mg}$ dan asam folat $0,25 \mathrm{mg}$ setiap minggu selama 8 minggu dapat menaikkan kadar $\mathrm{Hb}$ sebesar 0,68 $\pm 0,495$ dengan nilai $p$ value $=0,035$. Pemberian tablet $\mathrm{Fe}$ dan asam folat $2 \mathrm{kali} /$ minggu selama 8 minggu dapat menaikkan kadar $\mathrm{Hb}$ sebesar $0,98 \pm 0,347$ dengan nilai $p$ value $=0,032$ (Ariutami, 2012).

Atas dasar data tersebut maka penelitian ini bertujuan untuk mengetahui pengaruh pemberian tablet Fe dan vitamin $\mathrm{C}$. 


\section{METODE}

Rancangan penelitian adalah one group pre post test dengan variabel dependent kadar $\mathrm{Hb}$, $\mathrm{MCV}, \mathrm{MCH}$ dan MCHC. Variabel independen adalah suplementasi tablet $\mathrm{Fe}$ dan tablet vitamin C 500mg. Tablet Fe mengandung 60mg ferrous sulfat dan asam folat $400 \mathrm{mcg}$ (Kemenkes RI, 2014). Subjek penelitian adalah 41 mahasiswi Jurusan Analis Kesehatan Politeknik Kesehatan Tanjung Karang yang ditentukan secara acak. Suplementasi diberikan selama 17 hari dengan pemberian tablet Fe dan tablet vitamin $\mathrm{C}$ setiap 1 minggu sekali. Pengukuran kadar $\mathrm{Hb}, \mathrm{MCV}$, $\mathrm{MCH}$, dan MCHC dilakukan pada sebelum dan setelah suplementasi. Pengukuran tinggi badan dan berat badan dilakukan pada awal penelitian. Recall 2x 24 jam dilaksanakan pada sebelum dan setelah penelitian. Penelitian dilaksanakan pada bulan September-Agustus 2020. Untuk memonitoring dan mengingatkan jadwal konsumsi tablet suplementasi, dibuat grup whatsapp. Penelitian ini telah lulus laik etik oleh Komite Etik Penelitian Kesehatan Politeknik Kesehatan Tanjung Karang No 282/KEPKTJK/VII/2020.

\section{HASIL}

Tabel 1. Karakteristik Subjek

\begin{tabular}{lrr}
\hline Karakteristik & n & \multicolumn{1}{c}{$\%$} \\
\hline Usia & & \\
18 tahun & 4 & 9,76 \\
19 tahun & 29 & 70,73 \\
20 tahun & 7 & 17,07 \\
21 tahun & 1 & 2,44 \\
\hline Status Gizi & & \\
Kurang & 9 & 22,00 \\
$\quad$ Normal & 29 & 70,70 \\
$\quad$ Gemuk & 3 & 7,30 \\
\hline Lama haid & & \\
2-7 hari & 39 & 95,10 \\
$>7$ hari & 2 & 4,90 \\
\hline Status anemia & & \\
Anemia & 20 & 48,78 \\
Tidak Anemia & 21 & 51,22 \\
\hline
\end{tabular}

Subjek penelitian berjumlah 41 mahasiswi yang sebagian besar berusia 19 tahun $(70,73 \%)$. Sebagian besar subjek mempunyai status gizi normal walaupun masih terdapat $3(7,3 \%)$ subjek dengan status gizi gemuk dan $9(22 \%)$ subjek berstatus gizi kurang. Berdasarkan durasi haid, sebagian besar subjek mempunyai durasi haid 27 hari $(95,10 \%)$. Rata-rata kadar Hb subjek dalam batas normal yaitu sebesar 12,15 g/dl dengan median 12,20g/dl. Subjek dengan status anemia sebanyak 20 (48,78\%). Karakteristik subjek dapat dilihat pada tabel 1.Asupan zat gizi diperoleh melalui recall 2x 24 jam. Rata-rata asupan zat gizi masih di bawah kebutuhan, kecuali karbohidrat. Rata-rata persentase asupan energi $(76,51 \%)$, protein $(50,30 \%)$, lemak $(63,83 \%)$ dari kebutuhan. Rata-rata asupan vitamin dan mineral Fe (8,51mg), Zn (5,53mg), kalsium (306,40mg) dan vitamin $C(21,87 \mathrm{mg})$. Zat gizi dengan ratarata asupan di atas kebutuhan adalah karbohidrat yaitu sebesar 190,94\% dari kebutuhan. Rata-rata nilai indeks eritrosit masih di bawah batas nilai normal, yaitu $\mathrm{MCV}=80,12, \mathrm{MCH}=25,85 \mathrm{pg}$ dan $\mathrm{MCHC}=32,23 \%$.

\section{Tabel 2. Distribusi Asupan Zat Gizi}

\begin{tabular}{|c|c|c|}
\hline Asupan Zat Gizi & $\mathbf{n}$ & $\%$ \\
\hline \multicolumn{3}{|l|}{ Energi } \\
\hline$<70 \%$ & 15 & 36,60 \\
\hline $70-79 \%$ & 9 & 22,00 \\
\hline $80-89 \%$ & 8 & 19,50 \\
\hline $90-119 \%$ & 7 & 17,10 \\
\hline$\geq 120 \%$ & 2 & 4,90 \\
\hline \multicolumn{3}{|l|}{ Protein } \\
\hline$<70 \%$ & 24 & 58,50 \\
\hline $70-79 \%$ & 8 & 19,50 \\
\hline $80-89 \%$ & 4 & 9,80 \\
\hline $90-119 \%$ & 5 & 12,20 \\
\hline$\geq 120 \%$ & 0 & 0 \\
\hline \multicolumn{3}{|l|}{ Konsumsi Lemak } \\
\hline$<70 \%$ & 5 & 12,20 \\
\hline $70-79 \%$ & 5 & 12,20 \\
\hline $80-89 \%$ & 2 & 4,90 \\
\hline $90-119 \%$ & 13 & 31,70 \\
\hline$\geq 120 \%$ & 16 & 39,00 \\
\hline \multicolumn{3}{|l|}{ Konsumsi Karbohidrat } \\
\hline $70-79 \%$ & 1 & 2,44 \\
\hline $80-89 \%$ & 1 & 2,44 \\
\hline $90-119 \%$ & 4 & 9,75 \\
\hline$\geq 120 \%$ & 35 & 85,37 \\
\hline \multicolumn{3}{|l|}{$\mathrm{Fe}$} \\
\hline$<26 \mathrm{mg} /$ hari & 40 & 97,56 \\
\hline$\geq 26 \mathrm{mg} / \mathrm{hari}$ & 1 & 2,44 \\
\hline \multicolumn{3}{|l|}{$\mathbf{Z n}$} \\
\hline$<9 \mathrm{mg} / \mathrm{hari}$ & 40 & 97,56 \\
\hline$\geq 9 \mathrm{mg} /$ hari & 1 & 2,44 \\
\hline \multicolumn{3}{|l|}{$\mathrm{Ca}^{-}$} \\
\hline$<1200 \mathrm{mg} / \mathrm{hari}$ & 41 & 100,0 \\
\hline$\geq 1200 \mathrm{mg} / \mathrm{hari}$ & 0 & 0 \\
\hline \multicolumn{3}{|l|}{ Vitamin C } \\
\hline$<75 \mathrm{mg} /$ hari & 40 & 97,56 \\
\hline$\geq 75 \mathrm{mg} /$ hari & 1 & 2,44 \\
\hline
\end{tabular}

Asupan energi, protein, lemak dan karbohidrat dibedakan atas kategori deplesi berat $(<70 \%)$, sedang $(70-79 \%)$, ringan $(80-89 \%)$, normal (90-119\%) dan di atas kebutuhan $(>119 \%)$. Sebagian besar subjek mempunyai asupan energi kurang dari kebutuhan yaitu sebesar $32(78,05 \%)$ dan $2(4,90 \%)$ subjek 
dengan asupan melebihi kebutuhan. Sebanyak 36 $(87,20 \%)$ subjek mempunyai asupan protein kurang dari kebutuhan, dan $16(39,00 \%)$ subjek dengan asupan lemak berlebih.

Kebutuhan $\mathrm{Fe}, \mathrm{Zn}, \mathrm{Ca}$ dan vitamin $\mathrm{C}$, mengacu pada Angka Kecukupan Gizi yang Dianjurkan (Kemenkes RI, 2019). Asupan Fe, $\mathrm{Zn}, \mathrm{Ca}$, dan vitamin $\mathrm{C}$ dibedakan atas kategori kurang dan baik. Asupan $\mathrm{Fe}$ dikategorikan kurang jika asupan $(<26 \mathrm{mg} / \mathrm{hr})$ dan baik (>26mg/hari). Asupan Ca dikategorikan kurang $(<1200 \mathrm{mg})$ dan baik ( $\geq 1200 \mathrm{mg})$, asupan vitamin C dikategorikan kurang ( $<75 \mathrm{mg} /$ hari) dan baik ( $\geq 75 \mathrm{mg} / \mathrm{hari}$ ). Sebagian besar subjek mempunyai asupan $\mathrm{Fe}, \mathrm{Zn}, \mathrm{Ca}$ dan Vitamin $\mathrm{C}$ dalam kategori kurang. Subjek dengan asupan Fe dalam kategori kurang sebesar 97,56\%, Zn (97,56\%), dan vitamin C (97,56\%). Adapun asupan kalsium pada seluruh subjek penelitian dalam kategori kurang.

\section{Pengaruh Suplementasi terhadap Kadar Hb, MCV, MCH dan MCHC}

Tabel 3. Pengaruh suplementasi terhadap kadar $\mathbf{H b}$

\begin{tabular}{crrrrrrrr}
\hline \multirow{2}{*}{ Kadar Hb } & \multicolumn{4}{c}{ Post Suplementasi } & \multicolumn{3}{c}{ Total } & \multirow{2}{*}{ p-value } \\
\cline { 2 - 7 } & Anemia & $\%$ & Non anemia & $\%$ & n & $\%$ & \\
\hline Pre Suplementasi & 16 & 80 & 4 & 20 & 20 & 100 & 0,000 \\
Anemia & 0 & 0 & 21 & 100 & 21 & 100 & \\
Non anemia & & & & & & & &
\end{tabular}

Sebanyak $20(48,78 \%)$ subjek penelitian mempunyai kadar $\mathrm{Hb}<12 \mathrm{mg} / \mathrm{dl}$ pada pre suplementasi dan pada post suplementasi menjadi $16(39,02 \%)$ subjek. Walaupun proporsi anemia menurun pada post suplementasi, tetapi rata- rata kadar $\mathrm{Hb}$ subjek penelitian mengalami penurunan pada akhir penelitian. Rata-rata kadar $\mathrm{Hb}$ pada pre suplementasi sebesar $12,15 \mathrm{~g} / \mathrm{dl}$ dan setelah suplementasi menjadi $12,07 \mathrm{~g} / \mathrm{dl}$ dengan penurunan kadar $\mathrm{Hb}$ pada subjek yang anemia sebesar $-0,16 \mathrm{~g} / \mathrm{dl}$ dan subjek yang tidak anemia mengalami penurunan kadar $\mathrm{Hb}$ sebesar $-0,39$ $\mathrm{mg} / \mathrm{dl}$. Berdasarkan analisis fisher's exact test menunjukkan bahwa suplementasi berpengaruh terhadap kadar $\mathrm{Hb}$ dengan nilai $p$-value $=0,000$.

Tabel 4. Pengaruh Suplementasi terhadap Kadar MCV

\begin{tabular}{|c|c|c|c|c|c|c|c|}
\hline \multirow{2}{*}{ Kadar MCV } & \multicolumn{4}{|c|}{ Post Suplementasi } & \multicolumn{2}{|c|}{ Total } & \multirow[t]{2}{*}{ p-value } \\
\hline & $<82 \mathrm{fl}$ & $\%$ & $\geq 82 \mathrm{fl}$ & $\%$ & $\mathbf{n}$ & $\%$ & \\
\hline \multicolumn{8}{|l|}{ Pre Suplementasi } \\
\hline$<82 \mathrm{fl}$ & 15 & 88,2 & 2 & 11,8 & 17 & 100 & 0,000 \\
\hline$\geq 82 \mathrm{fl}$ & 1 & 4,2 & 23 & 95,8 & 24 & 100 & \\
\hline
\end{tabular}

Kategori kadar MCV subjek tidak berubah pada akhir penelitian. Rata-rata nilai MCV pre suplementasi sebesar 80,12fl dan post suplementasi sebesar 79,83fl. Rata-rata nilai mean corpuscular volume (MCV) pada post suplementasi mengalami penurunan sebesar 0,59 fl. Subjek dengan anemia mengalami penurunan nilai $\mathrm{MCV}$ rata-rata sebesar $0,14 \mathrm{fl}$, sedangkan subjek yang tidak anemia mengalami penurunan rata-rata nilai $\mathrm{MCV}$ sebesar 0,43fl. Proporsi subjek dengan nilai MCV <82fl sebanyak 17 $(41,46 \%)$ pada sebelum suplementasi, dan menurun menjadi $16 \quad(39,02 \%)$ setelah suplementasi. Proporsi subjek dengan nilai MCV normal naik dari $24(58,54 \%)$ menjadi 25 $(60,97 \%)$ subjek setelah suplementasi. Hasil uji chi square menunjukkan bahwa suplementasi berpengaruh terhadap nilai MCV dengans nilai $p$ value $=0,000$.

Tabel 5. Pengaruh Suplementasi terhadap Kadar MCH dan MCHC

\begin{tabular}{lcccccc}
\hline Indeks eritrosit & n & Mean & SD & SE & 95\% CI & p-value \\
\hline Nilai MCH & & & & & & \\
$\quad$ Pre suplementasi & 41 & 25,85 & 3,34 & 0,52 & $-0,8249--0,3897$ & 0,000 \\
$\quad$ Post Suplementasi & 41 & 26,45 & 3,42 & 0,53 & & \\
\hline Nilai MCHC & & & & & & \\
$\quad$ Pre suplementasi & 41 & 32,23 & 1,17 & 0,18 & $-1,1707--0,5269$ & 0,000 \\
$\quad$ Post suplementasi & 41 & 33,08 & 0,88 & 0,14 & & \\
\hline
\end{tabular}

Proporsi subjek dengan kadar $\mathrm{MCH}<27$ pg menurun dari $19(46,24 \%)$ subjek pada awal penelitian menjadi $15(36,58 \%)$ subjek pada post suplementasi. Rata-rata nilai MCH post 
suplementasi mengalami kenaikan 0,61pg. Ratarata kenaikan $\mathrm{MCH}$ pada subjek anemia sebesar 0,48pg dan pada subjek tanpa anemia sebesar 0,73 pg. Rata-rata nilai $\mathrm{MCH}$ mengalami peningkatan dari $25,85 \pm 3,34 \mathrm{pg}$ pada pre suplementasi menjadi $26,45 \pm 3,42$ pg pada post suplementasi. Uji fisher's exact test menunjukkan bahwa suplementasi berpengaruh terhadap kadar MCH ( $p$-value $=0000)$.

Proporsi subjek dengan nilai $\mathrm{MCHC}<32 \%$ menurun dari $12(29,27 \%)$ subjek pada pre suplementasi menjadi $7(17,07 \%)$ subjek pada post suplementasi. Rata-rata nilai $\mathrm{MCHC}$ mengalami peningkatan dari $32,23 \pm 1,17 \%$ pada pre suplementasi menjadi $33,08 \pm 0,88 \%$ pada post suplementasi. Uji paired $t$ test menunjukkan adanya pengaruh suplementasi terhadap nilai MCHC dengan $p$-value $=0,000$.

\section{PEMBAHASAN}

\section{Karakteristik Subjek}

Anemia adalah suatu keadaan dimana jumlah kadar hemoglobin $(\mathrm{Hb})$ di bawah normal. Hemoglobin merupakan metaloprotein dalam sel darah merah yang berfungsi untuk mengangkut oksigen dari paru-paru ke seluruh tubuh serta mengangkut $\mathrm{CO}_{2}$ dari seluruh tubuh menuju paru-paru untuk selanjutnya dihembuskan keluar dari tubuh (Amalia \& Tjiptaningrum, 2016). Prevalensi anemia di negara sedang berkembang berkisar 25-50\%, dan yang paling banyak merupakan anemia defisiensi besi (Kumar, 2015), dengan prevalensi tertinggi pada remaja dan wanita usia subur (Fikawati, 2017).

Menurut WHO, remaja adalah penduduk dengan rentang usai 10-19 tahun, sedangkan menurut Badan Kependudukan dan Keluarga Berencana $(\mathrm{BKKBN})$ rentang usia remaja adalah 10-24 tahun dan belum menikah (Kemenkes RI ${ }^{\mathrm{b}}$, 2015). Subjek penelitian adalah remaja putri dengan rentang usia 18-21 tahun dengan usia terbanyak adalah 19 tahun $(70,73 \%)$. Remaja putri mengalami siklus menstruasi setiap bulannya, yang mengakibatkan kehilangan volume darah setiap bulan berkisar 30-50 cc yang setara dengan kehilangan zat besi sebanyak 12,5$15 \mathrm{mg}$ perbulan (Fikawati, 2017) atau $0,5 \mathrm{mgFe} / \mathrm{ml}$ (Fitriany \& Saputri, 2018). Kehilangan zat besi pada remaja putri baik basal maupun lewat darah menstruasi bila ditotal berkisar $1,25 \mathrm{mg} /$ hari. Hal ini menjadikan remaja putri berisiko untuk mengalami anemia. Penelitian (Kristiani, et al., 2014) menunjukkan remaja putri dengan siklus menstruasi normal sebanyak $40 \%$ dan kategori tidak normal sebesar 60\%. Secara statistik terdapat hubungan yang signifikan antara siklus menstruasi dengan kejadian anemia pada remaja putri di SMA Negeri 1 Imogiri Bantul Yogyakarta ( $p$-value $=0,018)$.

Sebanyak 9 (22\%) subjek penelitian mempunyai status gizi kurus dan $3(7,3 \%)$ subjek mempunyai status gizi gemuk. Rata-rata kadar $\mathrm{Hb}$ subjek penelitian adalah $12,15 \mathrm{mg} / \mathrm{dl}$ dan sebanyak $20 \quad(48,78 \%)$ subjek mempunyai $\mathrm{Hb}<12 \mathrm{mg} / \mathrm{dl}$. (Sa, et al., 2017) menyampaikan bahwa jaringan adiposa dan hati memproduksi peptide hepcidin, yang diidentifikasi sebagai pengatur homeostasis besi. Hepcidin meningkat pada obesitas dan dapat berkontribusi pada terjadinya peningkatan prevalensi defisiensi besi pada populasi overweight. Peningkatan kadar hepcidin akan menurunkan absorbs zat besi di usus. Sebuah studi cross-sectional pada wanita Thailand menunjukkan bahwa obesitas dikaitkan dengan penurunan penyerapan zat besi. Penelitian pada anak usia sekolah menunjukkan bahwa anak-anak kelebihan berat badan memiliki konsentrasi hepcidin lebih tinggi dan status zat besi lebih rendah dibandingkan dengan anak dengan berat badan normal.

Hasil penelitian ini sejalan dengan penelitian pada mahasiswi Muslim Indonesia menunjukkan bahwa sebanyak 47,5\% mahasiswi mempunyai $\mathrm{Hb}<12 \mathrm{mg} / \mathrm{dl}$ (Dewi \& Yusriani, 2018). Sementara penelitian pada siswi SMA Negeri I Imogiri Bantul, Yogyakarta menunjukkan bahwa proporsi siswi yang menderita anemia sebesar $40 \%$ (Kristiani, et al., 2014). Anemia dikaitkan dengan meningkatnya morbiditas dan mortalitas, gangguan perkembangan kognitif dan perilaku. Penurunan persediaan zat besi dalam tubuh mengakibatkan efek negatif pada perkembangan dan fungsi otak bahkan sebelum anemia berkembang (Chaparro \& Suchdev, 2019).

Lama menstruasi normal adalah 2-7 hari. Sebanyak $39(45,10 \%)$ subjek penelitian mempunyai lama menstruasi 2-7 hari. Lama menstruasi berhubungan dengan kehilangan darah dan zat besi. Semakin lama durasi menstruasi, maka semakin banyak risiko kehilangan darah dan zat besi sehingga risiko anemia menjadi lebih besar. Kehilangan volume darah setiap bulan akibat menstruasi berkisar 30$50 \mathrm{cc}$ yang setara dengan kehilangan zat besi sebanyak 12,5-15mg perbulan (Fikawati, 2017) atau $0,5 \mathrm{mgFe} / \mathrm{ml}$ (Fitriany \& Saputri, 2018). Hal ini menjadikan remaja putri berisiko untuk mengalami anemia. Hasil penelitian pada mahasiswi Fakultas Kedokteran di Universitas Muslim Indonesia menunjukkan bahwa lama 
menstruasi berhubungan dengan kadar $\mathrm{Hb}$ (Dewi \& Yusriani, 2018).

Sebanyak $24(58,60 \%)$ subjek penelitian mempunyai asupan energi dalam kategori deplesi sedang dan berat, dan $2(4,90 \%)$ subjek mempunyai asupan energi melebihim kebutuhannya. Asupan energi yang rendah pada lebih dari setengah subjek penelitian disebabkan mereka jarang makan pagi serta makan siang yang mundur karena alasan menjalani perkuliahan praktikum laboratorium di masa pandemi covid-19 sehingga frekuensi makan antara 1-2 kali dalam sehari. Hasil penelitian kasus kontrol oleh (Agustina, 2016) pada anak Sekolah Menengah Pertama, Sekolah Menengah Atas dan Perguruan Tinggi di Kebumen menunjukkan adanya hubungan antara asupan energi dengan kejadian anemia ( $p$-value $=0,047$; OR 2,807).

Asupan protein pada $32(58,50 \%)$ subjek dalam kategori deplesi sedang dan berat dan 4 $(9,8 \%)$ subjek dalam kategori deplesi ringan. Asupan protein yang rendah, karena kurangnya konsumsi bahan makanan berupa lauk pauk. Sebanyak 20 (48,78\%) subjek mengkonsumsi lauk hewani berupa ayam, daging, ikan, dan hati ayam. Protein berupa jaringan hewan memiliki efek peningkatan pada absorbsi zat besi non heme. Namun protein susu sapi (kasein dan whey), dan putih telur terbukti menghambat absorbsi zat besi. Protein dari kedelai juga menurunkan absorbs zat besi (Sa, et al., 2017). Protein diperlukan sebagai alat transport zat besi. Transferin merupakan protein transport zat besi yang mengikat 2 molekul Fe (T.D. Coates, 2014)

Asupan lemak pada 16 (39\%) subjek di atas kebutuhan (>120\% kebutuhan), dan sebanyak $35(85,37 \%)$ subjek mempunyai asupan karbohidrat di atas kebutuhan. Tingginya asupan lemak dan karbohidrat karena asupan zat gizi lebih banyak diperoleh dari makanan jajanan yang tinggi karbohidrat dan lemak seperti bakwan, cimol, pempek, donat, siomay, dst.

Asupan $\mathrm{Fe}, \mathrm{Zn}$ dan vitamin $\mathrm{C}$ pada 40 $(97,56 \%)$ subjek dan asupan kalsium pada seluruh subjek di bawah kebutuhan. Asupan zat gizi tersebut rendah karena sebagian besar subjek tidak mengkonsumsi sayuran, buah maupun lauk hewani dalam jumlah yang cukup. Dalam hal ini perlu dilakukan upaya meningkatkan asupan zat gizi melalui edukasi tentang bahaya anemia, pentingnya zat gizi yang berperan dalam sintesa $\mathrm{Hb}$ serta akibat $\mathrm{Hb}$ yang rendah, agar dapat memperbaiki status anemia. Fe diperlukan dalam proses eritropoesis. Kekurangan zat besi akan menyebabkan gangguan hematopoesis dan metabolisme seluler, sedangkan kelebihan zat besi dapat mengakibatkan kematian sel karena pembentukan radikal bebas (Perdana \& Jacobus, 2015). Vitamin C mempermudah absorbsi zat besi non heme dengan mengubah ferri menjadi ferro yang lebih mudah untuk diabsorbi di usus halus. Zat besi dalam bentuk ferri $\left(\mathrm{Fe}^{3+}\right)$ banyak ditemukan pada makanan nabati, sementara dalam makanan hewani zat besi tersedia dalam bentuk ferro $(\mathrm{Fe} 2+)$. Vitamin $\mathrm{C}$ merupakan enhancer utama bagi absorbsi zat besi pada vegetarian (Sa, et al., 2017) (Chambial, et al., 2013); Fikawati, 2017). Asupan vitamin C berhubungan dengan kadar hemoglobin pada remaja putri di SMA Negeri I Manyar (Sholicha $\&$ Muniroh, 2019). Penelitian pada remaja vegan menunjukkan bahwa asupan vitamin $\mathrm{C}$ berhubungan dengan kadar $\mathrm{Hb}$ (Siallagan, et al., 2016).

Zat besi heme $\left(\mathrm{Fe}^{2+}\right)$ yang terdapat dalam makanan hewani lebih mudah diabsorbsi daripada zat besi non heme $\left(\mathrm{Fe}^{3+}\right)$. Zat besi heme banyak terdapat dalam daging merah, hati, ikan dan unggas, sedangkan zat besi non heme banyak ditemukan dalam biji-bijian, sayuran dan buahbuahan. Sebanyak $15-25 \%$ zat besi heme dapat diabsorbsi di duodenum dan yeyunum bagian atas, sedangkan dalam bentuk non heme hanya 5$20 \%$ yang dapat disabsorbsi (Santoyo-Sánchez, et al., 2015).

Asupan kalsium pada semua subjek dalam kategori kurang. Dengan demikian keterlibatan kalsium pada penurunan $\mathrm{Hb}$ bisa dikesampingkan, walaupun kalsium memiliki efek negatif pada penyerapan zat besi non heme dan heme. Hal ini yang membedakan kalsium dengan inhibitor lainnya seperti fitat dan polifenol yang hanya mempengaruhi absorbsi zat besi non heme (Sa, et al., 2017).

\section{Pengaruh Suplementasi terhadap Kadar Hb}

Proporsi subjek anemia pada pre suplementasi sebanyak $20(48,78 \%)$ subjek dan turun menjadi $16(30,02 \%)$ pada post suplementasi. Uji fisher,s exact menunjukkan bahwa suplementasi berpengaruh terhadap kadar $\mathrm{Hb}$ ( $p$-value $=0,000)$. Walaupun suplementasi $60 \mathrm{mg}$ ferrous sulfate, $400 \mathrm{mg}$ folat dan vitamin C $500 \mathrm{mg}$ setiap minggu belum dapat memenuhi kebutuhan $\mathrm{Fe}$ dan vitamin $\mathrm{C}$ harian subjek, tetapi suplementasi dapat meningkatkan asupan dan membantu proses eritropoesis, terutama pada subjek yang anemia.

Proporsi subjek dengan anemia terjadi penurunan pada post suplementasi, tetapi ratarata kadar $\mathrm{Hb}$ subjek penelitian juga mengalami penurunan. Sebanyak $20(48,78 \%)$ subjek 
mengalami penurunan kadar $\mathrm{Hb}$ dan $16(39,02 \%)$ subjek mengalami kenaikan kadar $\mathrm{Hb}$ dan 5 subjek tidak mengalami perubahan kadar $\mathrm{Hb}$. Hal ini disebabkan asupan $\mathrm{Fe}$ pada $97,56 \%$ subjek penelitian masih dalam kategori kurang dengan rata-rata sebesar $8,51 \mathrm{mg} /$ hari. Rata-rata penurunan kadar $\mathrm{Hb}$ sebesar $0,27 \mathrm{mg} / \mathrm{dl}$ dengan distribusi penurunan $0,16 \mathrm{mg} / \mathrm{dl}$ pada subjek yang anemia dan penurunan $0,39 \mathrm{mg} / \mathrm{dl}$ pada subjek tidak anemia.. Penurunan kadar $\mathrm{Hb}$ pada subjek yang mengalami anemia lebih kecil dibandingkan dengan subjek yang tidak anemia, karena pada kondisi defisiensi absorbsi $\mathrm{Fe}$ akan lebih tinggi dibandingkan yang tanpa defisiensi (Kurniati, 2020). Status besi individu mempengaruhi penyerapan zat besi non heme, sedangkan penyerapan zat besi heme umumnya kurang terpengaruh. Ada korelasi terbalik antara status besi dan absorpsi besi, dan dengan penggunaan feritin sebagai indikator status besi (Sa, et al., 2017). Untuk mengatasi kekurangan cadangan zat besi, tubuh akan beradaptasi dengan mempercepat penyerapan zat besi melalui usus untuk memenuhi permintaan besi yang meningkat secara relatif (Ernawati, et.al, 2018).

Sekitar $1 \mathrm{mg} /$ hari zat besi hilang terutama di mitokondria, kulit dan epitel usus (Ernawati, 2018). Pada remaja putri, volume darah setiap bulan akibat menstruasi berkisar 30-50cc yang setara dengan kehilangan zat besi sebanyak 12,5$15 \mathrm{mg}$ perbulan (Fikawati, 2017) atau $0,5 \mathrm{mgFe} / \mathrm{ml}$ (Fitriany \& Saputri, 2018). Pada saat asupan zat besi tidak mampu mengimbangi kehilangan zat besi maka simpanan zat besi tubuh berkurang. Ketika simpanan zat besi dalam bentuk haemosiderrin dan ferritin semakin menyusut dan tidak lagi mencukupi kebutuhan normal, pasokan zat besi ke protein transport apotransferrin juga menjadi terganggu. Hal ini mengakibatkan turunnya saturasi transferin dan peningkatan reseptor transferin dalam sirkulasi. Akhirnya produksi hemoglobin $(\mathrm{Hb})$ dan sel darah merah menurun akibat dari zat besi yang kurang (Ernawati, 2018). Selain defisiensi zat besi, anemia juga bisa terjadi akibat kekurangan zat gizi yang diperlukan untuk eritropoesis diantaranya vitamin B12, dan asam folat (Santoyo-Sánchez, et al., 2015). Adapun dalam penelitian ini tidak dilakukan perhitungan asupan vitamin B12 dan asam folat.

Suplementasi vitamin C memberikan tambahan asupan, walaupun belum bisa memenuhi kebutuhan vitamin $C$ subjek. Vitamin $\mathrm{C}$ berperan dalam meningkatkan absorbsi zat besi heme di usus. Efek peningkatan sebagian besar disebabkan oleh kemampuannya mereduksi $\mathrm{F}^{3+}$ menjadi $\mathrm{Fe}^{2+}$ tetapi juga karena potensinya pada kelasi besi. Asam askorbat akan mengatasi efek negatif semua inhibitor termasuk fitat, polifenol, kalsium dan protein susu pada absorpsi zat besi serta akan meningkatkan absorbs zat besi (Sa, et al., 2017). Penelitian dengan memberikan tablet besi pada wanita dewasa sebesar $100 \mathrm{mg}+200 \mathrm{mg}$ vitamin $\mathrm{C}$ dan pada kelompok kontrol diberikan tablet besi $100 \mathrm{mg}$ saja setiap 8 jam setiap hari selama 3 bulan, rata-rata kenaikan $\mathrm{Hb}$ pada kelompok kontrol sebesar $1,84 \pm 1,08 \mathrm{~g} / \mathrm{dl}$ dan pada kelompok dengan penambahan vitamin $\mathrm{C}$ terjadi kenaikan $\mathrm{Hb}$ sebesar $2 \pm 1,08 \mathrm{~g} / \mathrm{dl}(\mathrm{Li}$, et al., 2020).

Asupan protein ikut berperan pada penurunan kadar $\mathrm{Hb}$. Protein berperan sebagai alat transport zat besi. Protein berupa jaringan hewan memiliki efek peningkatan pada penyerapan zat besi non heme. Namun protein susu sapi (kasein dan whey), dan putih telur terbukti menghambat absorbs zat besi. Protein dari kedelai juga menurunkan absorbsi zat besi (Sa, et al., 2017). Asupan protein pada 36 $(87,80 \%)$ subjek yang dalam kategori deplesi ringan, sedang dan berat juga dapat berperan pada turunnya kadar $\mathrm{Hb}$ setelah suplementasi. Protein diperlukan dalam sintesa tranferin, yaitu suatu protein transport zat besi yang mengikat 2 molekul Fe (T.D. Coates, 2014).

Penurunan rata-rata kadar $\mathrm{Hb}$ setelah suplementasi disebabkan waktu penelitian yang kurang lama dan jumlah tablet Fe yang diberikan belum bisa mencukupi kebutuhan $\mathrm{Fe}$ subjek. Rata-rata asupan $\mathrm{Fe}$ subjek $8,15 \mathrm{mg} /$ hari dan kebutuhan $\mathrm{Fe}$ untuk remaja putri adalah 26mg/hari. Suplementasi 3 tablet tambah darah dengan kandungan $\mathrm{Fe}$ 60mg selama 17 hari, baru bisa memberikan tambahan asupan $\mathrm{Fe}$ sebesar $10,58 \mathrm{mg} /$ hari, sehingga asupan Fe total berkisar $19,73 \mathrm{mg} /$ hari yang berarti masih di bawah kebutuhan minimal Fe untuk remaja putri. WHO merekomendasikan pencegahan anemia dengan suplementasi $60 \mathrm{mg} / \mathrm{hari}$ selama 3 bulan berturutturut pada wanita usia produktif yang hamil, atau pada saat prevalensi anemia $>40 \%$. Pada kondisi di mana prevalensi anemia $>20 \%$, suplementasi bisa diberikan secara intermiten untuk meningkatkan status $\mathrm{Fe}$ dan mengurangi risiko anemia (WHO, 2016).

Hasil penelitian ini sejalan dengan penelitian pada ibu hamil anemia, di mana pemberian tablet $\mathrm{Fe}$ dan vitamin $\mathrm{C} 50 \mathrm{mg} / \mathrm{hari}$ selama 14 hari dapat meningkatkan kadar $\mathrm{Hb}$ dengan $p$-value $=0,0003$ (Agusmayanti, et al., 2020). Sementara itu penelitian pada 22 subjek dengan rancangan penelitian RCT dan pemberian suplementasi Fe 200mg dan asam folat $250 \mathrm{mg}$ setiap minggu serta $2 \mathrm{kali} /$ minggu selama 8 
minggu dapat menaikkan kadar $\mathrm{Hb}$ secara bermakna dengan nilai $p$-value $=0,035$ pada suplementasi mingguan dan $p$-value $=0,032$ pada suplementasi 2 kali/minggu (Ariutami, 2012). Suplementasi Fe $60 \mathrm{mg}$ dan folat $400 \mathrm{mcg}$ setiap hari pada ibu hamil selama 4 bulan di Ethiopia menunjukkan adanya peningkatan rata-rata kadar $\mathrm{Hb}$ sebesar $8,7 \%$, pada awal penelitian sebesar $11,5 \pm 0,3 \mathrm{mg} / \mathrm{dl}$ menjadi $12,5 \pm 1,2 \mathrm{mg} / \mathrm{dl}$ pada akhir penelitian dengan $p$-value $=0,001$ (Belay, et al., 2019).

Suplementasi ferrous sulfat selama 3 bulan pada ibu hamil dengan rancangan pre-post test design menunjukkan hasil yang berbeda. Suplementasi ferros sulfat selama 3 bulan tidak berpengaruh pada kadar $\mathrm{Hb}$ ibu hamil, walaupun suplementasi dapat meningkatkan kadar ferritin secara bermakna ( $p$-value $=0,008) \quad$ (Isfaizah \& Cahyaningrum, 2019). Suplementasi Fe pada tikus selama 18 hari dengan dosis $0,54 \mathrm{mg}$, $1,08 \mathrm{mg}$ dan $2,16 \mathrm{mg}$ dapat menurunkan jumlah sel $B$ pankreas secara bermakna, jumlah sel B pankreas berbeda bermakna antara kelompok control dengan kelompok perlakuan $(p$ value $=0,000$ ). Rata-rata jumlah sel $B$ pancreas terkecil adalah kelompok dengan suplementasi $\mathrm{Fe}$ paling besar (Aldi, et al., 2019).

\section{Pengaruh Suplementasi terhadap MCV, MCH dan MCHC}

MCV telah digunakan secara luas untuk mengevaluasi adanya defisiensi gizi besi. Nilai MCV memberikan gambaran ukuran rata-rata eritrosit. Nilai MCV normal berdasarkan adalah 82-92fl. Rata-rata nilai MCV pre suplementasi sebesar 80,12fl dan post suplementasi turun menjadi 79,83fl Rata-rata nilai mean corpuscular volume (MCV) pada post suplementasi mengalami penurunan sebesar 0,29fl. Subjek dengan anemia mengalami penurunan $\mathrm{MCV}$ ratarata sebesar $0,14 \mathrm{fl}$, sedangkan subjek yang tidak anemia mengalami penurunan rata-rata nilai MCV sebesar 0,43 fl. Penurunan rata-rata nilai MCV menunjukkan bahwa ukuran eritrosit lebih kecil dari normal, sebagai akibat defisiensi zat besi. Pada awal penelitian, subjek dengan nilai MCV<82fl sebanyak $17(41,46 \%)$ subjek dan $\mathrm{MCV} \geq 82 \mathrm{fl}$ sebanyak $24(58,54 \%)$ subjek dengan 1 subjek diantaranya mempunyai nilai MCV>92fl. Subjek penelitian dengan nilai $\mathrm{MCV}<82 \mathrm{fl}$ pada sebelum suplementasi sebanyak $17(41,46 \%)$ turun menjadi $16(39,02 \%)$ subjek pada post suplementasi. Subjek dengan nilai MCV $\geq 82-92 \mathrm{fl}$ pada sebelum suplementasi sebanyak $24(58,54 \%)$ subjek naik menjadi 25 $(60,97 \%)$ subjek pada post suplementasi. Uji chi square menunjukkan bahwa suplementasi berpengaruh bermakna terhadap nilai MCV ( $p$ value $=0,000$ )

Nilai $\mathrm{MCV}<82$ fl menunjukkan bahwa volume eritrosit di bawah normal (Kurniati, 2020). Nilai MCV yang kurang dari normal berarti ukuran eritrosit kurang dari normal (mikrositik). Hal ini menunjukkan bahwa anemia yang terjadi akibat defisiensi Fe. Penurunan nilai MCV post suplementasi disebabkan asupan $\mathrm{Fe}$ subjek belum mencukupi kebutuhan $\mathrm{Fe}$ harian sekalipun subjek sudah diberikan tablet tambah darah dengan kandungan ferrous sulfate $60 \mathrm{mg}$ dan asam folat $400 \mathrm{mcg}$ serta tablet vitamin C 500mg setiap minggu. Asupan protein subjek yang masih kurang dari kebutuhan ikut bertanggung jawab terhadap penurunan rata-rata nilai MCV. Dalam hal ini, protein berperan sebagai alat transport bagi Fe (Kurniati, 2020). Ditemukannya $1 \quad(2,43 \%)$ subjek yang mempunyai $\mathrm{MCV}>92 \mathrm{pg}$ menunjukkan adanya anemia makrositer pada subjek tersebut sebagai akibat defisiensi asam folat dan atau vitamin B12 (Ernawati, et al., 2018).

Penelitian pada ibu hamil selama 4 bulan di Ethiopia dengan melakukan suplementasi $\mathrm{Fe}$ $60 \mathrm{mg}$, folat $400 \mathrm{mcg} / \mathrm{hari}$ menunjukkan adanya penurunan nilai MCV baik pada kelompok ibu hamil anemia maupun ibu hamil tanpa anemia. Rata-rata nilai MCV pada kelompok ibu hamil anemia pada awal penelitian sebesar $87,1 \pm 7,5$ menurun menjadi $81,7 \pm 22,5$ dengan $p$ value $=0,08$. Sedangkan pada kelompok ibu hamil tanpa anemia rata-rata nilai MCV sebesar $85,1 \pm 11,7$ turun menjadi $83,7 \pm 19,6$ dengan $p$ value $=0,41$ (Belay, et al., 2019).

Jumlah subjek penelitian yang mengalami anemia sebanyak $20 \quad(48,78 \%)$ subjek, tetapi subjek dengan profil eritrosit mikrositik (nilai MCV<82fl) hanya sebesar $17(41,46 \%)$. Hal ini dapat dijelaskam, ketika cadangan besi telah menipis bahkan habis, zat besi pada kompartemen transportasi menurun drastis, sel darah merah tidak dapat berkembang secara normal. Jumlah sel prekursor meningkat karena akumulasi hemoglobin dalam sel melambat sehingga memungkinkan lebih banyak waktu untuk pembelahan sel dan menghasilkan sel darah merah yang lebih kecil atau mikrositik. Pada awalnya konsentrasi $\mathrm{Hb}$ pada sel sel darah merah yang kecil ini masih memadai, tetapi lama kelamaan menjadi semakin berkurang, maka terdapatlah gambaran sel darah merah yang mikrositik dan hipokromik (Ernawati, et al., 2018). Sebesar $40 \%$ pasien dengan anemia defisiensi besi memiliki eritrosit normositik (Johnson-Wimbley \& Graham, 2011). 
Mean corpuscular haemoglobin (MCH) mengukur rata-rata kandungan hemoglobin dalam sel darah merah. MCH dihitung berdasarkan rasio hemoglobin terhadap jumlah sel darah merah (Ernawati, et al, 2018). Nilai $\mathrm{MCH}$ normal adalah 27-31pg. Rata-rata nilai $\mathrm{MCH}$ post suplementasi mengalami kenaikan $0,61 \mathrm{pg}$. Rata-rata kenaikan nilai $\mathrm{MCH}$ pada subjek dengan anemia sebesar $0,48 \mathrm{pg}$ dan pada subjek tanpa anemia sebesar $0,73 \mathrm{pg}$. Sebanyak $19(46,34 \%)$ subjek mempunyai nilai $\mathrm{MCH}<27 \mathrm{pg}$ pada awal penelitian dan pada akhir penelitian turun menjadi 15 subjek $(36,59 \%)$. Nilai $\mathrm{MCH}$ yang kurang dari normal menunjukkan adanya anemia hipokromik akibat defisiensi $\mathrm{Fe}$ (Ernawati, et al., 2018). Asupan Fe pada semua subjek penelitian dalam kategori kurang, walaupun sudah ditambahkan dengan suplementasi tablet $\mathrm{Fe}$ secara mingguan selama 17 hari.

Rata-rata nilai $\mathrm{MCH}$ subjek penelitian pada pre suplementasi sebesar $25,85 \mathrm{pg}$ dan post suplementasi sebesar 26,45pg. Uji paired t test menunjukkan bahwa suplementasi memberikan pengaruh yang bermakna terhadap nilai $\mathrm{MCH}(p$ value $=0,000$; CI:-0,8249 hingga -0,3897). Nilai $\mathrm{MCH}<27 \mathrm{pg}$ menunjukkan bahwa adanya eritrosit hipokromik akibat jumlah $\mathrm{Hb}$ dalam eritrosit di bawah normal. Pada defisiensi besi yang parah, penurunan pada $\mathrm{MCH}$ relatif lebih besar daripada penurunan MCV pada kondisi yang sama (Ernawati, et al., 2018) Adapun peningkatan ratarata nilai $\mathrm{MCH}$ dari 25,85pg menjadi $26,45 \mathrm{pg}$ menunjukkan bahwa ketersediaan $\mathrm{Fe}$ dalam tubuh sudah meningkat dari sebelumnya walaupun belum sepenuhnya dapat memenuhi kebutuhan sehari. Hasil suplementasi $\mathrm{Fe} 60 \mathrm{mg}$ dan folat $400 \mathrm{mcg}$ pada ibu hamil non anemia dapat menaikkan nilai $\mathrm{MCH}$ secara bermakna ( $p$ value $=0,03$ ) tetapi pada ibu hamil anemia menunjukkan tidak ada pengaruh $(p$-value $=0,19)$ (Belay, et al., 2019).

Mean corpuscular haemoglobin (MCHC) merupakan rata- rata konsentrasi hemoglobin dalam sel darah merah. Pada defisiensi besi, indeks MCHC adalah yang paling terakhir mengalami penurunan setelah MCV dan $\mathrm{MCH}$. Nilai MCHC normal adalah 32-37\%. Pada anemia defisiensi besi nilai MCHC kurang dari normal, sedangkan pada anemia makrositik baik defisiensi vitamin B12, folat maupun pada anemia akibat penyakit kronis MCHC bernilai normal (Ernawati, et al., 2018). Rata-rata nilai MCHC pre suplementasi sebesar 32,23pg dan post suplementasi sebesar 33,08\%. Uji paired $t$ test menunjukkan bahwa suplementasi memberikan pengaruh yang bermakna terhadap nilai MCHC ( $p$-value $=0,000$; CI:-1,1707 hingga -0,5269). Terdapat penurunan proporsi subjek dengan MCHC $<32 \%$ dari $12(29,27 \%)$ subjek pada pre suplementasi menjadi $7(17,07 \%)$ post suplementasi. Nilai MCHC di bawah normal menunjukkan adanya hipokromia dan berhubungan dengan defisiensi besi tingkat lanjut (Ernawati, et al., 2018). Dengan demikian suplementasi dapat meningkatkan nilai MCHC. Hasil penelitian berbeda menyatakan bahwa suplementasi Fe $60 \mathrm{mg}$ dan folat $400 \mathrm{mcg}$ setiap hari selama 4 bulan tidak berpengaruh terhadap rata-rata $\mathrm{MCHC}$ ibu hamil yang anemia maupun ibu hamil non anemia dan terjadi penurunan rata-rata MCHC pada kelompok ibu hamil anemia dari $31,0 \pm 1,5 \%$ menjadi $30,3 \pm 2,5 \%$ dan pada kelompok ibu hamil non anemia dari $31,0 \pm 2,9 \%$ menjadi $30,7 \pm 2,8 \%$.

Nilai MCV dan dan MCH dapat menjadi indikasi adanya anemia defisiensi besi, penyakit kronik maupun talasemia (Kurniati, 2020). Kriteria penyakit kronik dan talasemia sudah dieksklusikan pada persyaratan subjek penelitian sehingga nilai $\mathrm{MCV}$ atau $\mathrm{MCH}$ yang rendah berkaitan dengan defisiensi zat besi. Anemia defisiensi besi terjadi dengan diawali adanya penurunan serum ferritin yang jika berlanjut akan diikuti dengan penurunan kadar besi dalam darah. Tahap selanjutnya adalah penurunan kadar $\mathrm{Hb}$, MCV, MCH, MCHC, hematokrit (Amalia \& Tjiptaningrum, 2016).

Ketika seseorang mengalami kekurangan zat besi, belum tentu ia mengalami anemia, demikian juga sebaliknya. Anemia yang terjadi akibat kekurangan zat besi merupakan dampak keseimbangan negatif zat besi yang berkepanjangan sehingga telah terjadi masalah pada kompartemen fungsional zat besi. (Ernawati et al., 2018).

\section{SIMPULAN}

Hasil uji statistik menunjukkan suplementasi tablet tambah darah dan vitamin $\mathrm{C}$ dapat menurunkan proporsi anemia dan memperbaiki status MCV. Suplementasi dapat meningkatkan nilai $\mathrm{MCH}$ dan MCHC pada remaja putri. Perlu dilakukan edukasi gizi kepada populasi mahasiswi, untuk meningkatkan asupan zat gizi terutama energi, protein, $\mathrm{Fe}$, dan vitamin C. Perlu dilakukan penelitian dengan waktu yang lebih lama menggunakan kelompok kontrol dengan perlakuan suplementasi yang lebih bervariasi. 


\section{DAFTAR PUSTAKA}

Agusmayanti, R., Farich, A., \& Anggraini, A. (2020). Pemberian Vitamin C Dapat Meningkatkan Kadar Hemoglobin Pada Ibu Hamil Anemia. Jurnal Kebidanan Malahayati, 6(3), 342-348. https://doi.org/10.33024/jkm.v6i3.1731

Agustina, E. E. (2016). Hubungan antara asupan zat gizi energi, protein, zat besi dan pola menstruasi dengan kejadian anemia pada remaja putri berdasarkan jenjang pendidikan di kabupaten kebumen. PROSIDING: Seminar Nasional Dan Presentasi Hasil-Hasil Penelitian Pengabdian Masyarakat HUBUNGAN, 1, 60-69.

Aldi, A. S. P., Kalsum, U., \& Fatmawati, F. (2019). Pengaruh Suplementasi Besi (Fe) Dosis Tinggi Terhadap Kondisi Sel Beta Pankreas pada Tikus Putih (Rattus Norvegicus) Strain Wistar Bunting. Journal of Issues in Midwifery, 3(1), 20-25.

Almatsier, Sunita (2012) Prinsip-Dasar Ilmu Gizi. Jakarta: Gramedia Pustaka Utama.

Amalia, A., \& Tjiptaningrum, A. (2016). Diagnosis dan Tatalaksana Anemia Defisiensi Besi Diagnosis and Management of Iron Deficiency Anemia. Majority, 5, 166-169.

Ariutami, K. R. (2012). Beda Kadar Hemoglobin Remaja Anemia Setelah Pemberian Suplementasi Tablet Besi Folat Satu Kali dan Dua Kali Per Minggu. [Skripsi]. Semarang: Ilmu Gizi, Fakultas Kedokteran, Universitas Diponegoro.

Bani, S., Hassanpour-Siahestalkhi, A., Hassanpour, S., Mommad-AlizadehCharandabi, S., Mirghafourvand, M., \& Javadzadeh, Y. (2014). Comparison of two iron supplementation methods on Hemoglobin level and Menstrual Bleeding in Tabriz students. Iranian Journal of Pediatric Hematology and Oncology, 4(1), 11-16.

http://www.ncbi.nlm.nih.gov/pubmed/2473 4158\%0Ahttp://www.pubmedcentral.nih.g ov/articlerender.fcgi?artid=PMC3980016

Belay, E., Endrias, A., Berihu, B. A., \& Endris, K. (2019). Correction: Hematological responses to iron-folate supplementation and its determinants in pregnant women attending antenatal cares in Mekelle City, Ethiopia (PLoS ONE (2018) 13: 10 (e0204791) DOI: 10.1371/journal.pone.0204791). PLoS
ONE, $\quad 14(2), \quad 212713$. https://doi.org/10.1371/journal.pone.02127 13

Chambial, S., Dwivedi, S., Shukla, K. K., John, P. J., \& Sharma, P. (2013). Vitamin C in disease prevention and cure: An overview. Indian Journal of Clinical Biochemistry, 28(4), 314-328. https://doi.org/10.1007/s12291-013-0375-3

Chaparro, C. M., \& Suchdev, P. S. (2019). Anemia epidemiology, pathophysiology, and etiology in low- and middle-income countries. Annals of the New York Academy of Sciences, 1450(1), 15-31. https://doi.org/10.1111/nyas.14092

Dewi, C., \& Yusriani, K. (2018). Hubungan Antara Lama Menstruasi Dengan Kadar Hemoglobin Pada Mahasiswi Fakultas Kedokteran Universitas Muslim Indonesia Angkatan 2016. Window of Health, 1(1), 56-60.

Dumilah, P. R. A., \& Sumarmi, S. (2017). Hubungan Anemia Dengan Prestasi Belajar Siswi Di SMP Unggulan Bina Insani. Amerta Nutrition, 1(4), 331. https://doi.org/10.20473/amnt.v1i4.7140

Ernawati F; Oktaria Y; Khomsan A. (2018). Peluang Generasi Bangsa yang Terabaikan Anemia Baduta. Bogor: IPB Press.

Fikawati, Sandra; Syafiq, Ahmad; Veratamala, Arinda, (2017), Gizi Anak dan Remaja, Depok: Rajawali Pers.

Fitriany, J., \& Saputri, A. I. (2018). Anemia Defisiensi Besi. Jurnal. Kesehatan Masyarakat, 4(1202005126), 1-30.

Hardinsyah, (2016) Ilmu Gizi Teori \& Aplikasinya. Jakarta: EGC.

Isfaizah, I., \& Cahyaningrum, C. (2019). Efektifitas Suplementasi Ferro Sulfat (Fe) Dalam Meningkatkan Kadar Ferritin Pada Ibu Hamil Trimester I. Medika Respati : Jurnal Ilmiah Kesehatan, 14(4), 301. https://doi.org/10.35842/mr.v14i4.167

Johnson-Wimbley, T. D., \& Graham, D. Y. (2011). Diagnosis and management of iron deficiency anemia in the 21st century. Therapeutic Advances in Gastroenterology, 4(3), 177-184. https://doi.org/10.1177/1756283X11398736

Kemenkes. (2015). Riset Kesehatan Dasar. https://doi.org/10.1517/13543784.7.5.803

Kemenkes RI ${ }^{\mathrm{b}}$. (2015). Situasi Kesehatan Reproduksi Remaja. Jakarta Pusat Data dan Informasi Kementerian Kesehatan RI. 
https://www.kemkes.go.id/resources/downl oad/pusdatin/infodatin/infodatin\%20reprod uksi\%20remaja-ed.pdf

Kemenkes RI. (2014), Standar Tablet Tambah Darah bagi wanita Usia Subur dan Ibu Hamil. Jakarta: Permenkes RI 2014.

Kemenkes RI. (2019). Angka Kecukupan Gizi Yang Dianjurkan untuk Masyarakat Indonesia. Jakarta: Permenkes Nomor 28 Tahun 2019.

Kemenkes RI. (2019). Profil Kesehatan Indonesia 2018 [Indonesia Health Profile 2018].

http://www.depkes.go.id/resources/downlo ad/pusdatin/profil-kesehatan-

indonesia/Data-dan-Informasi_Profil-

Kesehatan-Indonesia-2018.pdf

Kristiani, S., Wibowo, T. A., \& Winarsih. (2014). Hubungan Anemia dengan Siklus Menstruasi pada Remaja Putri di SMA Negeri 1 Imogiri, Bantul, Yogyakarta Tahun 2013. Jurnal Studi Pemuda, 3(1), 33-38.

Kumar, V., Abbas, A. K., Aster, J. C., Cornain, S., \& Nasar, I. M. (Eds.). (2015). Buku Ajar Patologi Robbins. Singapore, Elsevier.

Kurniati, I. (2020). Anemia Defisiensi Zat Besi (Fe) Iron Deficiency (Fe) Anemia. Jurnal Kedokteran Universitas Lampung, 4(1), 18-33.

Li, N., Zhao, G., Wu, W., Zhang, M., Liu, W., Chen, Q., \& Wang, X. (2020). The Efficacy and Safety of Vitamin C for Iron Supplementation in Adult Patients With Iron Deficiency Anemia: A Randomized Clinical Trial. JAMA Network Open, 3(11), e2023644.

https://doi.org/10.1001/jamanetworkopen.2 020.23644

Masthalina, H. (2015). Pola Konsumsi (Faktor Inhibitor Dan Enhancer $\mathrm{Fe}$ ) Terhadap
Status Anemia Remaja Putri. Jurnal Kesehatan Masyarakat, 11(1), 80. https://doi.org/10.15294/kemas.v11i1.3516

Perdana, W. Y., \& Jacobus, D. J. (2015). Hepcidin dan Anemia Defi siensi Besi. Cdk-235, 42(12), 919-926

Sa, S., Of, A., \& Ao, O. (2017). Iron: From Dietary Sources to Utilization in the Body. 1-7. https://doi.org/10.19080/GJN.2017.03.555 615

Santoyo-Sánchez, A., Aponte-Castillo, J. A., Parra-Peña, R. I., \& Ramos-Peñafiel, C. O. (2015). Dietary recommendations in patients with deficiency anaemia. Revista Médica Del Hospital General De México, 78(3),

144-150. https://doi.org/10.1016/j.hgmx.2015.06.002 .

Sholicha, C. A., \& Muniroh, L. (2019). Hubungan Asupan Zat Besi , Protein , Vitamin C Dan Pola Menstruasi Dengan Kadar Hemoglobin Pada Remaja Putri di SMAN 1 Manyar Gresik. Media Gizi Indonesia, 14(2), 147-153.

Siallagan, D., Swamilaksita, P. D., \& Angkasa, D. (2016). Pengaruh asupan Fe, vitamin A, vitamin B12, dan vitamin C terhadap kadar hemoglobin pada remaja vegan. Jurnal Gizi Klinik Indonesia, 13(2), 67. https://doi.org/10.22146/ijen.22921.

T.D. Coates. (2014). Physiology and Pathophysiology of Iron in HemoglobinAssociated Diseases. Free Radical Biology and Medicine, 72(3), 23-40. https://doi.org/10.1016/j.freeradbiomed.20 14.03.039.Physiology.

WHO. (2016) Daily Iron Supllementation In Adult Woman and Adolescents Girls Guideline.

https://www.who.int/nutrition/publications/ micronutrients/guidelines/daily_iron_supp _womenandgirls/en/ 